Bauna, Radar Tanjung. 2009. "Melacak Kontinum Kebijakan Kebudayaan di Indonesia". Makalah Dipresentasikan dalam Seminar Nasional Kebudayaan dan Studium General Sekolah Aktivis di Auditorium UNY, 4 Juni.

Geertz, Clifford. 1989. Abangan, Santri, Priyayi dalam Masyarakat Jawa. Jakarta: Pustaka Jaya.

Heilbroner, Robert L. 1991. Hakekat dan Logika Kapitalisme. Jakarta: LP3ES.

Kayam, Umar. 1981. Seni Tradisi Masyarakat. Jakarta: PT Sinar Harapan.

Langer, Susan K. 2006. Problematika Seni. Bandung: Sunan Ambu Press.

Peursen, Van CV. 1976. Strategi Kebudayaan. Yogyakarta: Kanisius.

Piliang, Yasraf Amir. 2004. Dunia Yang Dilipat. Yogyakarta: Jalasutra.

Smiers, Joost. 2009. Arts Under Pressure: Memperjuangkan Keanekaragaman Budaya di Era Globalisasi. Yogyakarta: Insist Press.

Soekito, Wiratmo. 1992. "Transformasi Kebudayaan dalam Era Globalisasi". Basis XLINo. 12. Yogyakarta.

Soedarsono, RM. 1985. "Pola Kehidupan Seni Pertunjukan Masyarakat Pedesaan" dalam Surjo, Djoko (et. al.). Gaya Hidup Masyarakat Jawa di Pedesaan: Pola Kehidupan Sosial-Ekonomi dan Budaya. Yogyakarta: Proyek Penelitian dan Pengkajian Kebudayaan Nusantara.

Sutiyono. 1991. "Dampak Pengembangan Kepariwisataan dalam Kehidupan Seni Rakyat." Cakrawala Pendidikan No. 1, Th. X. Penerbit Pusat Pengabdian Pada Masyarakat IKIPYogyakarta, pp. 103-116.

Sutiyono. 1994. "Seni Rakyat dalam Arus Globalisasi Ekonomi." Cakrawala Pendidikan No. 3, Th. XIII. Penerbit Pusat Pengabdian Pada Masyarakat IKIPYogyakarta, pp. 17-30.

\section{WAYANG TOPENG MALANG \\ DALAM PERUBAHAN KEBUDAYAAN}

\section{Robby Hidajat}

\author{
Mahasiswa Pascasarjana ISI Yogyakarta
}

\section{Abstract}

Musk puppet in Malang has a very special and distinctive presentation, that is consisting of some parts or acts in the forms of scenes: the Gending Giro traditional music, follwed with an opening dance Tari Patih, Jejeran, Grebek, Tari Bapang and Tari Gunungsari, ended with the scene of the meeting between Panji Asmarabangun and Candrakirana. The development of mask puppet in Malang as a cultural expression is very much influenced by the aspects of time, environment, and technological development especially information technology.

Keywords: puppet, musk, cultural changes

\section{PENDAHULUAN}

Penyajian wayang topeng di Malang dapat diperhatikan pada pagelaran yang disajikan oleh perkumpulan wayang topeng Asmorobangun dari Dusun Kedungmonggo Kecamatan Pakisaji Kabupaten Malang, yaitu sebagai beirkut:

\section{Adegan Pembukaan : Tari Patih}

Setelah gending giro selesai dibunyikan pertunjukan utama segera dimulai. Para panjak (niyaga/penggamel) 'penabuh gamelan' berhenti sejenak, mereka mulai mempersiapkan diri untuk memulai pertunjukan. Sebagian besar di antara mereka menggunakan jeda tersebut untuk cemilan kue-kue yang berupa ketela pohon, ubi, atau pisang rebus, dan tidak ketinggalan minum kopi hangat.

Ki dalang juga menyiapkan diri, membuka beberapa catatan khusus yang nanti harus diucapkan. Seringkali dalang berbincang-bincang dengan pengendang. Mereka membicarakan sesuatu yang berkaitan dengan sesuatu yang harus disepakati, khususnya peralihan adegan atau waktu-waktu memulai adegan dan mengakhirinya.

Setelah jeda dianggap cukup, pembonang (penabuh instrumen Bonang) mulai membunyikan instrumennya untuk mengawali gending Beskalan. (Gending Beskalan dilakukan dengan buka bonang). Gending ini khusus untuk mengawali pertunjukan Wayang Topeng Dusun Kedungmonggo. Gending Beskalan ini juga digunakan untuk tari putri pada pembukaan wayang kulit atau pertunjukan tayub 
kuna. Akan tetapi gending Beskalan pada wayang topeng Kedungmonggo sebagai musik tari topeng patih, yaitu sebuah bentuk tari pembukaan yang ditarikan oleh dua orang penari bertopeng abang (merah) dan putih (putih). Penduduk setempa seringkali menyebut dengan istilah topeng bang-tih (akronim dari abang dan putih), atau Beskalan Patih. Tradisi pembukaan dengan atraksi tari sesuatu yang sifatnya umum di Jawa timur, hal ini dimungkinkan terkait dengan pendirian candi bentar, candi lawang; sebuah bangunan gerbang menuju candi utama.

Bonang mulai dibunyikan (buka bonang), berikutnya disahut tepakan kendang, selanjutnya diikuti secara serentak instrumen gamelan lainnya. Tidak lama kemudian, terdengar suara gongseng berbunyi. Suara gongseng tersebut sangat jelas terdengar dari balik slambu. Kedua penari topeng putih keluar terlebih dahulu, berikutnya diikuti oleh penari yang bertopeng merah. Gerakan dua penari Topeng Patih ini sama, mirip komposisi tari bersama. Gerakan mereka adalah tergolong jenis kasaran.

Menurut beberapa informan, yang dimulai dari keterangan Madya Utomo, menjelaskan bahwa Beskalan berasal dari istilah bahasa Jawa setempat (Malang) yaitu dari akar kata bit-kal. Bit berawal dari kata Bibit atau bakal, dan kal berasa dari kata cikal atau awal (kawitan), perpaduan dari kata tersebut menjadi kata cikal-bakal atau bibit kawit, yaitu asal mula. Hal ini dibenarkan juga oleh Rasimoen dan Karimoen. Bahwa Beskalan itu memang benar berasal dari kata bahasa Jawa yang disebut cikal, yang artinya awal atau permulaan. Pengertian in ditambahkan oleh Sumantri, bahwa kata cikal itu berkaitan dengan kelapa (cikal) Hubungan ini menunjukkan adanya kaitan dengan sebutan gending kalapa ndhek (kelapa pendek), gending tersebut kemudian dikenal dengan sebutan Gending Beskalan. Sumantri menandaskan, bahwa istilah Gending Beskalan dalam kalangan masyarakat tayub sebenarnya tidak populer, tetapi istilah kelapa ndhek cukup dikenal. Sungguhpun Chattam AR masih meragukan, tetapi disadari benar, bahwa ada kemungkinannya istilah itu bersifat lokal atau nama kelapa ndhek itu dikenal masyarakat dalam masa tertentu.

Moch. Soleh Adipramono mendukung, bahwa pengertian istilah Beskalan itu memiliki makna awal atau permulaan. Kata beskalan seringkali dikaitkan dengan "bakal" atau "bakalan", yaitu barang yang belum jadi. Artinya masih berupa bahan baku.

Pertimbangan itu dikaitkan dengan seni pertunjukan yang erat kaitannya dengan tarian tersebut, seperti ludruk atau tayub. Pada seni pertunjukan ludruk atau tayub pada waktu yang lampau selalu diawali dengan sajian tari Beskalan sebagai tari pembukaan. Dengan demikian pengertian itu ada benarnya. Asumsi M. Soleh Adipramono ini dibenarkan juga oleh Chattam A.R., mengingat dalam wayang topeng Malang tari pembukaan, yaitu tari yang untuk mengawali pertunjukan juga disajikan tari Beskalan Patih. Tarian ini berupa tari putra yang disajikan dua orang yang memakai topeng putih (bisa marah putih), adapun gending tarian tersebut adalah gending Beskalan. Tidaklah mustahil kalau gending tersebut sudah akrab dengan masyarakat penikmatnya. Tetapi, Chattam A.R. juga menambahkan, bahwa bisa jadi Beskalan yang diartikan sebagai awal atau permulaan itu merupakan arti yang sesungguhnya dalam perkembangan tari di Malang, yaitu sebuah bentuk tari yang merupakan sumber atau tari yang mengawali semua bentuk tari yang berkembang, utamanya tari yang berkembang pada seni pertunjukan Tayub atau tari Remo (tari yang sekarang menjadi tari pembukaan sebelum dipertunjukkan Sandiwara Ludruk).

\section{Jejer Sabrang}

Jejer Sabrang adalah adegan yang menggambarkan situasi pada kerajaan yang disebut kerajaan Sabrang Istilah "Sabrang" pada mulanya adalah digunakan oleh Raja Mataram, Panembahan Senopati (1575-1601), yaitu untuk menyebut wilayah-wilayah yang akan ditaklukkan (di luar pusat/kerajaan). Waktu itu, wilayah yang direncanakan untuk diserang adalah Jawa bagian timur, yang disebut sebagai "brang-wetan". Istilah "brang-wetan" ini dipandang dari posisi sentral yaitu Mataram, sedangkan Jawa bagian barat disebut "brang kulon”. Kata "brang" adalah kependekan dari kata "Sabrang" atau "seberang", yaitu suatu daerah di luar batas wilayah (Moertono, 1985: 132).

Para pemangku wayang topeng di Dusun Kedungmonggo mengartikan Sabrang sebagai wilayah yang dikuasai oleh raja-raja yang berwatak angkara murka, kasar penampilannya, dan jahat perilakunya. Raja-raja penguasa kerajaan Sabrang umumnya disebut sebagai Wong Sabrang. Rajanya Wong Sabrang tersebut mempunyai sebutan atau gelar sebagai nama depan, yaitu Klana. Gambaran dari Wong Sabrang, atau raja sabrang seringkali dicandra oleh $k i$ Dhalang seperti berikut.

Klana sebagai sebuah sebutan kebesaran raja sabrang dipersepsi berasal dari kata "Lelana" atau berkelana, yaitu suatu keputusan dari seseorang yang meninggalkan tempat tinggalnya untuk pergi mencari sesuatu, apakah ilmu pengetahuan atau pekerjaan. Berkelana atau mengembara seringkali untuk menggambarkan para satria Jawa mencari "kamukten", umumnya yang berada dalam lakon Mahabarata, seperti Raden Harjuna atau Janaka, salah seorang dari lima bersaudara dari Pandawa yang selalu mengadakan perjalanan untuk mencari ilmu kanuragan atau Jayakawijayan. Klana Sewandana dalam cerita Panji memiliki pemahaman yang mengarah pada suatu tindakan pribadi, yaitu "laku" untuk mencari pengalaman, pengetahuan, dan kesaktian. Kata "laku", yang kemudian digunakan sebagai sebuah tindakan (kata kerja) menjadi istilah "lelaku" atau "ngelakoni" (menjalankan suatu ketirakatan). Hal ini dikenakan secara umum dari para satria Jawa, termasuk Panji Panji digambarkan seperti Harjuna yang 
selalu pergi mengembara mencari istirinya, yaitu dewi Candrakirana yang hilang atau meninggalkan kerajaan dengan diam-diam. Pengembaraan ini memiliki analogi dengan satria panengah Pandawa yang disebut Harjuna, dia selalu meninggalkan kerajaan untuk berkelana dengan harapan dapat mencapa keunggulan dalam perang besar Baratayuda. Panji atau Harjuna dipersepsi sama tujuannya, yaitu mencari "kejayaan" atau "kamukten" pada masa depan, yaitu mengarah pada pencapaian yang disebut "kamukten", atau kejayaan.

"Lelana" atau "laku" atau "ngelakoni" merupakan suatu proses yang untuk menyadarkan eksistensi diri. Karimoen menjelaskan bahwa kondisi manusia selalu dalam kondisi labil, diliputi emosi, ambisius, diliputi berbaga keinginan yang bersifat materialistis, duniawi, termasuk nafsu birahi (wawancara 12 Maret 2003). Para satria Jawa dalam pertunjukan Wayang Purwa digambarkan sebagai bentuk pengembaraan yang disebut lenana. Perjalanan satria selalu dijaga atau didampingi oleh Panakawan yang berjumlah 4 orang. Panakawan juga disebut abdi atau batur yang dipahami sebagai embating piatur, yaitu teman untuk mempertimbangkan segala sesuatu yang akan diputuskan.

Klana dalam lakon Panji ditangkap sebagai suatu figur yang selalu dalam posisi menentang kebaikan, atau disebut sebagai tokoh antagonistik. Tokoh antagonis menjadi lawan abadi Panji, yaitu sebagai tokoh yang menegakkan kebenaran, atau disebut sebagai tokoh protagonistik. Meskipun demikian, para pemangku wayang topeng di Dusun Kedungmonggo tidak hanya melihat secara kontradiksi. Mereka lebih melihat adanya suatu kecenderungan umum dalam dir manusia, yaitu manusia memiliki adanya sifat seperti Klana dan sekaligus juga sifat seperti Panji, atau mempunyai sifat angkara dan sekaligus juga sifat kebaikan Keduanya harus selalu saling mengalami proses penyeimbangan, dengan harapan yang angkara tidak mendominasi yang baik dan juga sebaliknya. Kedua oposisional tersebut menunjukkan suatu yang disebut sebagai "laku”.

Klana dan Panji tidak dipahami sebagai sebuah bentuk perlawanan yang bersifat kontradiksi, tetapi keduanya adalah suatu bentuk yang dapat memberikan pengertian yang bersifat mempribadi, yaitu sebuah konflik batin yang dinyatakan secara visual. Pemahaman ini menjadi beralasan, jika kerajaan Sabrang itu tidak pernah dapat ditunjukkan dalam pemahaman kongkrit, tetapi menunjuk tempat yang bersifat imajiner, liar, atau tidak beradab. Sabrang letaknya jauh dari jangkauan diri manusia, atau jauh dari diri manusia. Persepsi tentang Sabrang menunjukkan adanya dikotomi dengan "pusat", yaitu sebuah otonomi negara sebagai pemukiman orang Jawa, atau kerajaan Jawa. Fenomena ini dapat disimak lebih mendalam seperti berikut.

Sebuah cara untuk ikut serta mencerminkan kekuasan pusat dalam berbagai tingkat. Akhirnya jauh di pinggiran, tanah olehan dan desa-desa mengalah pada hutan dan barisan pegunungan - wilayah "liar" di luar jangkauan pusat kekuasaan. Wilayah ini sama sekali bukan tanpa daya; sebaliknya, wilayah ini penuh dengan kekuasaan; akan tetapi sifatnya anarki, kacau balau dan zaman purba. Hanya orang yang betul-betul berada di pusat dapat menundukkan kekuatan-kekuatan itu dengan meditasi dan disiplin diri. Memang, ruang yang mantap, beradab dan “jinak"-kerajaan, negara (Gesick, 1989: xix).

Jejer Sabrang selalu menunjukkan situasi yang penuh dengan hasrat, ambisi, luapan harapan, dan tuntutan nafsu birahi yang tak tertahankan, bahkan tidak jarang disertai luapan kemarahan yang membara, meledak-ledak seakan tidak tertahankan. Karena kondisi ini menunjukkan adanya simbol kondisi orang muda. Masa muda membuat orang selalu dipenuhi dengan berbagai hal yang tidak pernah dapat dikendalikan sendiri oleh dirinya. Prabu Kelana Sewandana dilukiskan seperti berikut.

...ketika gending Gagak Setro dibunyikan, seketika itu slambu (tirai) penghalang antara pentas dan tempat ganti pakaian wayang bergetar, tampak dipegang oleh seseorang. Getaran slambu tersebut seiring dengan getaran irama gending, bahkan diselingi oleh bunyi gongseng yang dihentakkan (gedrug) oleh kaki penari, tidak lama kemudian tiba-tiba slambu dibuka, tampak sosok penari bertopeng merah, mengenakan jamang tropong, tetapi tidak lama kemudian slambu ditutup kembali. Genap tiga kali membuka slambu, kemudian penari bertopeng merah tersebut keluar menggunakan gerak sirik, dan tiba-tiba jeluat (membalik) lalu jengkeng (jongkok) melakukan gerakan sembahan menghadap ke slambu (membelakangi penonton). Tidak lama kemudian, berdiri dan labas (jalan), yang diakhir dengan junjungan kaki. Topeng klana yang merah pekat kehitaman itu semakin tampak garang, matanya yang melotot, serta muka topeng yang selalu menoleh kekanan dan kekiri. Seakan-akan tokoh yang berperawakan tinggi besar ini akan terbang... (pengamatan pertunjukan penyajian wayang topeng lakon Panji Krama 15 Agustus 2010).

Tokoh yang bertopeng merah tua tersebut dikenali oleh penontonnya dengan nama Klana, umumnya dikenal dengan sebutan Klana Sewandana. Dalam bebagai versi cerita, Klana mempunyai sebutan yang berbeda-beda, seperti Klana Garudayaksa, Klana Timbul Taunan, atau Klana Baron Sekeber. Tokoh ini umumnya dibawakan oleh orang yang bertubuh tinggi besar, kaki dan tangannya kuat (kukuh), gerakannya bervolume lebar, dan arah gerak yang tegas. Gerakan tokoh Klana menunjukkan seorang raja yang sedang mabuk kepayang, bahkan selalu digambarkan sedang tergila-gila pada seorang putri dari kerajaan Kediri 
(Daha), yang bernama Dewi Galuh Candrakirana atau disebut dengan nama lain Sekartaji. Ambisi dan birahinya ditampakkan pada gerakan yang disebut dengan "Solah raja" sejenis motif gerak "kiprahan", yaitu gerakan orang yang bercanda, bahkan menunjukkan seperti orang yang sedang menghadapi gadis pujaannya (gandrungan), melakukan gerak kudangan (gandrungan) yang disertai dengan vokal sebagai berikut berikut.

Gerakan Klana Sewandana tampak agresif dan dinamis, hal ini menunjukkan bahwa tokoh ini memililiki kekuatan yang luar biasa, bahkan mempunyai kekuasaan yang bersifat otoriter; tindakannya selalu memaksakan kehendak karena selalu menuruti nafsu yang bergejolak dalam hatinya.

Busana tokoh Klana kini lebih ditegaskan karakteristiknya, yaitu mengenakan busana serba merah. Pada perkembangannya seringkali digunakan variasi warna lain seperti warna sampur (kain yang lentur dan tipis sepanjang kurang lebih dua setengah meter lebar tiga puluh senti yang dikalungkan pada leher) yang merah diganti dengan sampur warna kuning, atau merah muda.

Pencandraan demikian ini mengambarkan, bahwa, Klana adalah seorang raksasa yang mengganggu manusia. Bahkan merupakan penguasa alam gaib dan dunia roh-roh jahat. Penggambaran ini memiliki kemiripan dengan Syiwa sebagai kekuatan penghancur, yaitu seringkali digambarkan dalam wayang purwa sebagai Brahala atau manivestasi Krisna sebagai wujud raksasa.

Kaitan relasional antara Klana, Syiwa, dan Brahala (Krisna) dalam lakonlakon Wayang Topeng relevan karena dalam lakon Panji tidak digambarkan perwujudan manusia yang berwatak angkara, seperti Suyudana (dalam Baratayuda), atau Rahwana (dalam Ramayana). Sungguhpun demikian keberadaan Klana memiliki kemiripan dengan Rahwana atau Dasamuka, yaitu sebuah perwujudan simbolik yang memiliki makna negatif, yaitu sebaga penggambaran penyimpangan etika, terutama yang berkaitan dengan hasrat ingin memiliki istri orang lain. Tindakan semacam ini dalam budaya Jawa disebut dengan "merusak pagar ayu". Tindakan ini sangat dibenci, bahkan suku Madura memandang tindakan menginginkan istri orang lain sebagai aib bagi laki-laki. Jika hal tersebut menimpa laki-laki Madura, sudah dapat dipastikan ia akan mempertaruhkan nyawanya dengan cara "carok". Watak suku Madura itulah yang diwarisi masyarakat Dusun Kedungmonggo, khususnya keluarga Karimoen. Watak etnik madura yang mengalir dalam diri Karimoen tersebut memberi warna pada wayang topeng di Dusun Kedungmonggo. Ciri etnik yang sangat kua mempengaruhi bentuk gerak tari topeng, terutama pada motif-motif gerak tari kasar.

Susunan motif gerak secara hirarkis menonjolkan karakteristik seorang yang bertemperamental; adigung-adiguna karena berkuasa, sakti, dan memiliki kekuatan penghancur. Klana dapat diidentikkan dengan sifat Syiwa yang merupakan dewa penghancur. Analogi ini dibangun oleh sifat oposisional antara Wisnu (Panji) dan Syiwa (Klana).

Struktur motif gerak tari Klana juga didukung oleh keberadaan tari Grebeg Sabrang, yaitu tari prajurit yang berangkat menuju medan perang. Dalam wayang kulit disebut dengan Rampokan, yaitu sejumlah prajurit yang berbaris di alun-alun. Adegan tersebut digambarkan dengan gerakan rampak (tari bersama), formasi tari yang lurus atau sejajar. Umumnya prajurit sabrang pada adegan grebeg dibawakan oleh empat orang penari, posisi mereka mengarah ke depan (penonton), membuat formasi bisa bejajar dua sap, atau berbanjar lurus ke belakang (sekarang formasi berjajar ini seringkali dibuat secara diagonal). Formasi yang menunjukkan adanya kekuatan yang bersifat magis adalah gerak melingkar, biasanya dengan menggunakan gejekan, atau labas dan gelap yang dilakukan dengan cara berputar membuat angka delapan yang disebut ngendali, atau bergerak melingkar searah dengan putaran jarum jam yang disebut prapatan 'formasi segiempat'.

Tari Klana dan Grebeg Sabrang merupakan sebuah rangkaian yang berada dalam adegan Sabrangan karena keduanya terpaut oleh tujuan-tujuan yang diperbincangkan dalam "paseban agung" (pertemuan antara Prabu Klana dan wadyabalanya). Watak kedua tarian ini memiliki nuansa karakteristik yang saling berpautan atau melengkapi. Adegan "paseban" dan "grebeg" merupakan kondisi yang bersifat "jaba-jero" (luar dalam).

\section{(1) Grebeg (Adegan barisan prajurid)}

Grebeg atau Garebeg adalah kata bahasa Jawa, artinya adalah diirid ing bala akeh (diiringi oleh prajurit yang banyak) (Djumadi dalam J.J. Ras, 1985: 335). Thojib Djumadi menjelaskan lebih lanjut tentang Grebeg, sebagai berikut.

Grebegan iku wis kalumrah sadurunge jaman Islam ing Indonesia. Ana ngendi-endi para nata yen tindak mesti ginarebeg ing sakehing bala. Apa maneh yen tindak menyang njaban kuta. Ananging grebegan kanti teges adat tata-cara uga wis ana ing jaman samana. Sataun sepisan para nata ginarebeg tindak miyos mubeng kuta. Mestine ing wektu mangkono mau sang prabu ora klepyan atur peparing wujud duwit apa dene busana lan bojana marang para penderek lumebere marang para kawula.

Sang pujangga Kanakamuni sing peparab sang Prapanca ing buku seratane "desyawarnana" sing luwih kasuwur kanti aran "Negarakertagama" nyaritakake adat mangkono mau ing jaman sugenge sang prabu Rajasanegara. Wektune saben tanggal 15 sasi Palguna. Tindake sang prabu ginarebeg ing para arya, para patih, mahasenapati, para senapati, tumenggung, rangga, kanurohan, demang, pelaut, panewu, pangalasan, bayangkari (Djumadi dalam J.J. Ras, 1985: 335). 
Pada wayang topeng adegan Grebeg menggambarkan barisan prajurit yang berangkat menunaikan titah sang raja, mereka keluar dari paseban menuju alun-alun untuk menyiapkan pasukan, kemudian menunaikan titah raja. Titah ini yang dimaksudkan sebagai "mandat", raja memberikan mandat pada seorang patih atau panglima untuk menyampaikan sesuatu yang beris keinginan tertentu. Titah di sini ada dua, yaitu titah yang baik dan ada pula yang jelek. Kedua titah ini akan dibawa oleh masing-masing utusan.

Grebeg dalam pertunjukan wayang topeng ada dua jenis yaitu Grebeg Jawa dan Grebeg Sabrang. Grebeg Jawa adalah menggambarkan barisan prajurit kerajaan Jawa, yaitu Kediri atau Jenggala. Gerebeg Sabrang adalah menggambarkan barisan prajurit kerajaan Sabrang. Berikut ini salah satu gambaran tentang adegan Grebeg Jawa.

Setelah jejer kerajaan Jenggala berakhir, sang prabu Lembu Amiluhur berserta pemaisuri meninggalkan paseban memasuki keraton, kemudian satu persatu kadang 'saudara' Panji berserta prajurit meninggalkan paseban itu juga.

Berikutnya adegan Grebeg Jawa, satu persatu kadang Panji yang terdiri dari Panji Pambela, Panji Pamecut, Panji Pamindu, dan Panji memasuki arena pentas dengan terlebih dahulu melewati slambu yang dibelah tepat di tengah-tengah sebagai layar belakang. Grebeg umumnya terdiri dari empat penari, jika lebih (5 orang) diikuti oleh sang raja. Gerakan tarian ini umumnya berpola jalan, yang menggunakan bentuk jalan bermacam-macam secara bergantian. Gerakan kaki yang pokok adalah Labas, gelap, atau Kencak. Adegan ini mempunyai pola perapatan (segiempat) dan melingkar satu kali penuh, atau melingkar dua kali berlawanan arah yang disebut ngendali.

Perbedaan dengan Grebeg Sabrang terletak pada materi gerak, karakter, dan motif gerak yang lebih besar (volume gerak lebar), juga bentukbentuk gerak yang lebih menonjolkan kekuatan, seperti gerak srodokan, atau gerak labas yang lebih lebar. Formasi yang dibuat umumnya tidak berbeda. Namun, pada perkembangan penyajian wayang topeng, formasi Grebeg ada yang berpola diagonal (menyudut), dengan gerakan wiwil jekluk yang dilanjutkan dengan penthangan.

Gambaran yang menunjukkan perjalanan para barisan prajurit pada saat adegan Grebeg, Moch. Soleh Adipramono seorang dalang yang serin membantu penyajian wayang topeng Kedungmonggo menunjukkan sulukan sewaktu mengawali adegan tersebut sebagai berikut.

Sigeg...sigeg kokngraosaken nanggih tumapak boten. Sigeg kang den pocapaken, budhale para wadyabala saking alun-alun mlebet pajagalan kampung mebel ngalor stitik kampung arab, belok ngalor ngetan kampung pecinan, ngalor maneh klojen ledok, munggah ngalor ngetan oro-oro dawa nrabas ngetan karang pedesan mbulak, mbunul, karang keceput, terus ngetan lampahe para prajurit. Hieg..sampun cekap nyariosaken lakune wadyabala, pating bleber pindo laru dipa, laru laron, dipa damar. Yen cinandra lampahing prajurit pinda laron nempuh uruping damar. Sandangane sarwa kembar. Kang ijo kaya suradhadhu, kang kuning kumpul padha kuning, kaya podhang manggih kemasan. Kang putih kumpul pada putih, kaya kuntul neba. Sing iring kumpul padha ireng pindo kalong medal karahinan. Lampahira wadyabala pinda sela blekiti. Sela watu, blekiti semut. Patrape prajurit kaya semut medal ngisoring watu. (M. Soleh Adipramono, wawancara 2 Januari 2003)

Secara umum suluk tersebut menggambarkan perjalanan prajurit yang melewati daerah-daerah di kota Malang. Di samping menggambarkan busana prajurit yang berwarna putih, kuning, hitam, dan hijau, Suluk juga menggambarkan banyaknya prajurit seperti semut.

\section{(2) Jejer Jawa}

Jejer atau jejeran atau juga disebut adeg-adeg adalah adegan yang menggambarkan sebuah pertemuan antara seorang raja, patih, dan para punggawa istana. Jejer berasal dari kata Jejek, atau tegak. Artinya sama dengan istilah adeg-adeg. Adegan mempunyai pengertian bagian yang mengemukakan eksistensial dari seorang penguasa, raja dan mereka yang dipimpin, termasuk penonton dapat dianggap sebagai rakyat yang sedang mengikuti berbagai pembicaraan, yaitu sabda sang raja.

Pada wayang topeng terdapat dua macam jejer, yaitu Jejer Jawa dan Jejer Sabrang. Kedua jenis jejer dibedakan karena pelaku dan tempat (kerajaan). Jejer Jawa pada umunya menampilkan kerajaan-kerajaan Jawa, yaitu: Kerajaan Jengala atau Jenggala Manik dengan rajanya bernama Lembu Amiluhur dan kerajaan Kediri (Daha) dengan rajanya Lembu Amijaya, dan Kerajaan Singasari dengan rajanya Lembu Amisasi, kerajaan Ngurawan dengan rajaya Lembu Amerdhadhu.

Jejer Sabrang menampilkan kerajaan-kerajaan dari tanah Seberang atau kerajaan di luar Jawa. Kerajaan Sabrang ada berbagai versi seperti: Kerajaan Rancang Kencana, Kerajaan Rancang Mutiara, Kerajaan Cemara Sewu, Kerajaan Bantarangin, dan lain sebagainya. Adapun raja-raja yang berkuasa umumnya disebut Klana, dalam berbagai versi Klana memiliki nama-nama yang khas, seperti; Klana Lindu Buwana, Klana Sewandana, Klana Garudayaksa, Klana Bledhek Lingga Buwana, dan lain sebagainnya. Pada umumnya tokoh-tokoh sabrang ini mempunyai watak yang kasar, istilah 
lokalnya brangasan. Temuan tersebut dijelaskan oleh Hasim Amir, bahwa Sabrang dalam pertunjukan wayang kulit (purwa) seperti yang dikemukakan dalam bukunya Nilai-nilai Etis Dalam Wayang, seperti berikut.

...kerajaan sabrang (adegan Sabrangan). Raja dari kerajaan sabrang biasanya adalah musuh raja dari kerayaan yang pertama (jejer Jawa). Dan selalu digambarkan sebagai raja yang serba berlawanan dengan raja yang pertama (sabrang berarti di luar Jawa, dan in mengimplikasikan watak raja yang tidak Jawa, artinya jelek atau jahat). Ia adalah tokoh antagonis dalam cerita ini. Dalam persidangan raja seberang, juga dibicarakan masalah kenegaraan yang penyelesaiannya yang mesti melibatkan pertentangan dengan raja yang pertama. Raja ini pun kemudian memutuskan mengirim utusan untuk melaksanakan kehendaknya $(1997,55)$.

\section{(3) Selingan}

Selingan adalah menyela adegan. Masyarakat penonton wayang topeng menyebut dengan istilah "ekstra" Adegan ini merupakan bagian yang tidak memiliki kaitan konstruktif, tetapi menjadi bagian yang bersifat integra dengan keseluruhan sajian. Adegan selingan mirip dengan adegan BambangCakil, yakni dalam wayang orang atau wayang kulit purwa. Isi adegan ini adalah munculnya tokoh Bapang yang membawakan tari Bapang, yaitu tokoh yang hadir dalam bentuk konstruktif tari tersendiri. Penampilannya selalu diiringi dengan Panakawan yang bernama Demang Mundu. Bapang tidak terkait dengan adegan jejer atau persoalan-persoalan yang dilakonkan Pemunculan tokoh Bapang merupakan bentuk presentasi tarian, yaitu menggambarkan perjalanan Bapang menuju negara kakaknya, yaitu Klana Sewandana. Setelah munculnya tari Bapang, kemudian dilanjutkan dengan Permainan Gunungsari - Patrajaya. Adegan ini sangat menarik karena terdapat bentuk gerak tari yang disebut dengan "permainan". Gunungsari dan Patrajaya bersama-sama memperagakan bentuk-bentuk yang khas, seperti: merak ngigel, merak ngombe, merak kesereten, wader pari nyungsung beji, merak kesimpir, biyodo mususi, wulanjar luru kemiri, satria jala, kemanten purek, tikus ngungak salang ngelur gadhung, dan lain sebagainya.

Menurut Karimoen, bentuk permainan dari Gunungsari berjumlah 24 macam, tetapi sekarang sudah jarang ditampilan karena terlalu lama, Penyajian pertunjukan yang terlalu lama mengakibatkan penonton merasa jenuh. Dampak negatif perubahan pola penyajian wayang topeng terhadap penari muda adalah menurunnya minat untuk mempelajari ragam gerak secara utuh, mereka mempelajari sesuai dengan kebutuhan penampilan. Kondisi in mengakibatkan penari-penari muda jarang yang bersedia untuk berperan rangkap, mereka tampil sesuai dengan peran yang biasa dipresentasikan saja.

Permainan Gunungsari-Patrajaya merupakan gerak tari yang bagus di antara gerak tari topeng yang lain. Demikian juga teknik gerak tarinya yang sulit dan berat cara menarikannya. Sebagai contoh gerak merak ngombe 'merak minum' dan merakngigel 'merak menari'.

Menuju gerakan merak ngombe diawali dengan gerak biyada mususi. Gerakan merak ngombe dilakukan dengan cara jengkeng dengan kaki kanan di depan (posisi duduk jegang). Tangan direntangkan miwir sampur, kepala digerakkan seperti burung sedang minum di sebuah telaga, kekuatan untuk mengarahkan berada di leher lentur yang diimbangi oleh badan yang mengikuti gerak kepala turun naik. Posisi dada kuat menahan dan mendorong gerak leher dan kepala sesekali ditarik ke belakang. Gerakan ini bisa dilakukan sedikitnya delapan kali.

Setelah melakukan merak ngombe, penari dapat langsung berpindah pada gerakan merak ngigel. Gerakan ini diawali dengan cara memutar kedua lengan tangan sehingga telapak tangan yang miwir sampur terbalik menghadap ke belakang. Sementara itu badan dibungkukkan di depan mengikuti kepala yang dijuntaikan hampir mendekati lantai. Setelah itu kaki kanan yang berada di depan digeserkan ke samping dengan menggunakan telapak kaki. Sementara lutut kiri menumpu badan mengikuti putaran kaki dan badan ke arah jarum jam.

\section{(4) Pertemuan Panji Asmarabangun-Dewi Sekartaji}

Adegan ini tidak memiliki sebutan, tetapi berbagai lakon selalu berakhir pada perjumpaan antara Panji Asmarabangun dan Sekartaji. Mereka berdua bertemu dan berbahagia, dapat diibaratkan secara metaforis "langit dan bumi", di atas tampak adanya kurva sebagai metafora langit yang dilalui oleh "matahari dan bulan". Garis horisontal menunjukkan sebuah bentuk "gelaran" yang merentang struktur sajian wayang topeng. Diawali dari giro, tari Beskalan patih, jejer (Jawa atau Sabrang), selanjutnya dipertunjukkan adegan Bapang; Gunungsari - Patrajaya, berikutnnya adegan perangan dan di akhiri dengan adegan "panggih" (pertemuan)

Adegan akhir ini bukan berarti selesai atau identik dengan "bubaran", tetapi ini adalah sebuah titik awal dari sebuah perjalanan baru yang berbentuk "siklus". Pertunjukan wayang topeng lebih memberikan pemahaman tentang "waktu" atau "kala". Manusia hidup sangat ditentukan oleh waktu, maka kalau tidak mengindahkan "waktu" atau "kala" tentu akan di makan, dilindas, ditelan. Bagaikan mitologi Jawa tenang "Betara Kala". 


\section{PERSEBARAN WAYANG TOPENG MALANG}

Bukti bahwa pertunjukan topeng tersebar di berbagai desa di Malang raya ditunjukan tulisan Th. Pigeaud dalam bukunya berjudul: Javaansche Volksbertoningen (Seni Pertunjukan Rakyat Jawa). Pada tahun 1928 di Kabupaten Malang terdapat 21 koleksi topeng. Pemain-pemain topeng yang terkenal asalnya dari Desa Pucangsongo di Kecamatan Tumpang; di zaman dahulu kepala desa tersebut, yang bernama: Saritruno, terkenal karena pandai menari topeng. Belum Lama ini di Malang dan sekitarnya semua pemuda dan priyayi harus dapat menari topeng; karena itu pada pesta-pesta tidak jarang tari topeng dilakukan oleh para priyayi...topeng masih dibuat di Kecamatan Karangploso (sekarang termasuk wilayah Kecamatan Belimbing - Kota Malang) oleh pengukir dan penari legendaris bernama Reni (Pigeaud. 1938: 217).

M. Soleh Adipramono dari Tumpang. Ia salah satu keturunan dalang topeng yang bernama Kek Tirtonoto. Usahanya dalam mengembangkan Wayang Topeng dimotivasi oleh keluarganya, sehingga darah seni yang mengalir dalam tubuhnya adalah tanggung jawab moral.

M. Soleh Adipramono meyakini tokoh yang bernama Reni dari Dusun Palawijen tersebut se-zaman dengan tokoh topeng dari Pucangsongo yang bernan Kek Ruminten. Kek Tirtonoto menceritakan kepada M. Soleh Adipramono. Ketika terjadi banjir kali 'sungai' Amprong yang bermataair di pegunungan Tengger, Ruminten seorang penduduk Desa Pucangsonggo, Kecamatan Pancokusumo pergi melihat genangan air kesawahnya. Waktu itu air masih pasang, bahkan sawah-sawah di desa itu semuanya terendam, bahkan di beberapa bagian dialiri ai bah yang cukup deras. Tiba-tiba di dekatnya terdapat potongan batang pohon, penduduk se tempat menyebut dengan istilah: Dugel. Batang kayu yang hanyut itu berhenti di dekat Kek Ruminten, kemudian kayu tersebut diambil dengan harapan dapat digunakan untuk diang 'perapian untuk penghangat ruangan'. Setelah kayu tersebut dikeringkan, kemudian dibakar. Ternyata kayu tersebut tidak termakan api. Kemudian timbul niat untuk dijadikan topeng. Dari potongan kayu yang kurang lebih $50 \mathrm{~cm}$ itu dibelah dan dipotong menjadi 4 bagian, masing-masing dijadikan topeng Klana, Gunungsari, Panji Asmorobangun, dan Patrajaya (M.Soleh, wawancara 3 Januari 2010).

Topeng-topeng itulah yang dianggap pertama kali sebagai cikal bakal keberadaan wayang topeng di Dusun Pucangsanga sekitar awal abad XX. Bisa jad keberadaan topeng di Pucangsanga tersebut yang pernah dicatat oleh Th. Pigeaud dari keterangan seorang lurah bernama Saritruno, di Pucangsanga. Kek Ruminten adalah kemenakan Reni, pengukir topeng dari Dusun Palawijen. (Supriyanto \& Adipramono. 1997: 7; Onghokham, 1972)

Karimoen dari Dusun Kedungmonggo juga membenarkan bahwa pemahat topeng yang terkenal di Malang dari Karangpeloso yaitu di Desa
Palawijen, sekarang Kecamatan Blimbing, Malang yang bernama Reni. Reni adalah guru Gurawan dari Dusun Mbangeran, Wijiombo, Gunung Kawi. Menurut Chattam AR. Atas keterangan mbah Wiji, penari legendaris dari Kopral, Sumberpucung. Orang yang disebut oleh Karimoen bernama Gurawan adalah Dulrahman putra Wedana Kepanjen. Waktu Dulrahman berlatih atau pentas di Pendapa Kabupaten Malang, mbah Wiji mengikuti dan melihat. Pengalaman itu, kemudian mbah Wiji dapat membuat topeng dan menari Topeng.

Sejarawan Onghokham juga mencatat kisah tentang Reni dan kelompok wayang topeng dari daerah lain. Onghokham juga secara khusus menceritakan tentang Reni yang berkaitan kaitannya dengan tokoh Wayang Topeng dari Desa Jabung yaitu Kangsen. Keterangan lebih lanjut tentang Reni menurut Onghokham.

Pada tahun 1930-an seorang petani kaya yang bernama Reni tinggal di desa ini (Polowijen). Dia adalah salah satu pembuat topeng terbesar gaya Malang dan memimpin salah satu rombongan wayang topeng terbaik pada masanya. Di dunia wayang topeng Malang kini, Desa Polowijen terkenal sebagai desa Reni. Pada masanya, wayang topeng mencapai salah satu titik puncak. Perkembangan ini tentu saja sebagaian disebabkan oleh sumbangan dari Bupati Malang pada waktu itu, R.A.A. Soeria Adiningrat, yang menyuplai Reni dengan bahanbahannya (lempengan emas tipis, cat yang baik, kayu) dan membantu menetapkan standar artistik (Onghokham. 1972).

Pertunjukan Wayang Topeng di daerah Malang sejak masa popularitas Reni telah tersebar di banyak tempat, khususnya di desa-desa. Persebaran wayang topeng meliputi Wajak, Dampit, Senggreng, Ngajum, dan di daerah lainnya (Timoer, 1989). Sekitar tahun tahun 1970-80-an masih ditemukan informasi tentang keberadaan tokoh-tokoh wayang topeng yang tersebar di berbagai desa di Kabupaten Malang. Seperti ditemukannya salah satu tokoh wayang topeng yang berusia 100 tahun yang bernama Wiji dari Desa Kopral Sumberpucung. Wiji memiliki sejumlah pengalaman yang pada umumnya tidak berbeda dengan tokohtokoh wayang topeng yang lain, seperti halnya Reni. Mbah Wiji pernah dikenal sebagai dalang wayang topeng, pengukir topeng, dan penari. Topeng-topengnya banyak dibeli oleh perkumpulan Wayang Topeng di Desa Jenggala, Kecamatan Kepanjen

Seorang penari dan pemahat topeng yang bernama Kusnan Ngaisah lahir tahun 1920-an di Dusun Slelir, Desa Bakalan Krajan, Kota Malang. Sekarang Kusnan Ngaisah tidak lagi menekuni wayang topeng karena membuat topeng tidak dapat memberikan penghasilan yang cukup. Sehingga, Kusnan memilih menjadi tukang kayu dan pekerja bangunan

Kusnan Ngaisah berhenti menjadi penari topeng, pengukir topeng dan sekaligus pimpinan wayang topeng di desanya sejak tahun 1960-an. Karena wayang topeng tersaingi oleh kepopuleran pertunjukan Ludruk. Akibatnya 
tanggapan wayang topeng menjadi berkurang. Waktu itu untuk membina pemain baru juga sudah sangat sukar. Karena para pemuda di Dusun Slelir lebih memilih sebagai pekerja kasar di kota. Kusnan Ngaisah juga memperhatikan perhatian masyarakat terhadap wayang topeng semakin berkurang, salah satu sebab adalah tidak lagi ada orang yang memperkuat pembiayaan organisasi. Kondisi seperti ini juga dialami oleh perkumpulan wayang topeng di Dusun Jabung. Ketika Kangsen meninggal dunia, perkumpulan wayang topeng di Dusun Jabung semakin melemah pendukungnya.

Informasi perihal perkembangan wayang topeng di Dusun Slelir didapatkan dari Kusnan Ngaisan, salah satu penari yang pernah belajar dari kakek mertua, bernama Nata. Penduduk se tempat menyebut Yai Nata. Ia adalah salah seorang pengukir kayu kepercayaan Bupati Malang.

Menurut Kusnan, Yai Nata merupakan orang serba bisa, termasuk kepandaiannya sebagai pengukir topeng. Waktu Yai Nata juga mengenal pengukir topeng dan sekaligus penari topeng yang terkenal bernama Reni dari Polowijen Reni tinggal di daerah Malang bagian utara, sedangkan Yai Nata tinggal di daerah Malang sebelah barat. Perkumpulan wayang topeng yang ada di Malang bagian barat dan selatan memesan topeng pada Yai Nata. Termasuk perkumpulan wayang topeng dari Desa Jatiguwi, Kecamatan Sumberpucung.

Keberadaan wayang topeng di Dusun Slelir berasal dari seorang pelatih dari Desa Panjer, Turen, Kabupaten Malang. Waktu itu sekitar tahun 1930-an, Kusnan Ngaisan waktu itu masih kecil, belum khitan. Tetapi dia sudah sering melihat orang berlatih dan pentas wayang topeng. Semua perlengkapan pentas, termasuk topeng dibuat oleh Yai Nata. (Kusnan Ngaisah, wawancara 9 Januari 2003)

Sekitar tahun 1930-an di Malang cukup banyak perkumpulan wayang topeng, termasuk di daerah Malang bagian selatan, yaitu di daerah Senggereng, Jenggala, Wijiamba, dan Turen. Perkumpulan wayang topeng yang satu dengan perkumpulan yang lain masih saling berhubungan. Kontak antara perkumpulan yang satu dengan perkumpulan yang lain dikarenakan kebutuhan pengadaan topeng. Perkumpulan yang tidak mempunyai pengukir topeng selalu memesan pada seniman pengukir topeng dari daerah lain. Mengingat waktu itu tidak banyak seniman pengukir topeng. Hanya beberapa seniman yang mempunyai kemampuan mengukir topeng, seperti Yai Nata dari Dusun Slelir. Di daerah Malang bagian utara hanya ada pengukir topeng yang bernama Reni. (Seperti yang ditulis oleh Onghokham). Di daerah Malang bagian selatan dikenal pengukir topeng yang bernama Wiji. Pada tahun 50-an muncul pengukir topeng bernama Kangsen dari Dusun Jabung. Sementara Karimoen dari Dusun Kedungmonggo mulai dikenal masyarakat luas sebagai pengukir topeng sejak tahun 1970-an.
Kontak antar perkumpulan wayang topeng yang satu dengan wayang topeng yang lain disebabkan juga oleh kebutuhan pelatihan tari, topeng, dan dalang. Seperti Samut, salah satu tokoh legendaris pemeran Gunungsari. Lelaki yang memiliki gerak-gerik yang luwes cenderung keputri-putrian banyak membina perkumpulan wayang topeng di daerah Malang bagian Timur. Sekitar tahun 1940-an Samut getol membina banyak perkumpulan wayang topeng bersama dalang bernama Kek Tirtonoto (Kakek M. Soleh AP) anak dari Rusman. Salah satu tokoh yang populer sebagai penari kasar. Rusman selain dikenal sebagai penari kasar juga sangat terampil memainkan instrumen pengendang. Tokoh-tokoh tersebut bersama Kek Rakhim mengembangkan wayang topeng di Malang bagian Timur hingga tahun 1970-an (Murgiyanto \& Munardi, 1978/79: $31)$.

Munardi salah seorang guru SMK IX (d/h SMKI, sebelumnya Konservatori) di Surabaya mulai tahun 1972 tertarik wayang topeng di Malang. Selanjutnya, Munardi mengadakan pengamatan perkembangan wayang topeng di Malang. Waktu itu Munardi tergabung dengan seniman-seniman di Dewan Kesenian Surabaya. Ketertarikan Munardi terhadap Wayang Topeng Malang banyak mendapat dukungan, terutama pemerintah daerah. Sejak saat itu, Munardi secara khusus mencurahkan perhatiannya pada perkembangan topeng di Malang, bahkan hasil observasinya telah ditulis menjadi sebuah buku berjudul Wayang Topeng Malang. Buku tersebut ditulis bersama Sal Murgiyanto. Tulisan tersebut juga menginformasikan sejumlah lokasi yang memiliki perkumpulan wayang topeng.

Di masa lalu pertunjukan Wayang Topeng Malang agaknya tersebar luas di berbagai wilayah Kebupaten Malang; Dampit, Precet, Wajak, Ngajum, Jatiguwi, Senggreng, Pucangsanga, Jabung, dan Kedungmongoo. Akan tetapi, sekarang pada akhir tahun 1970-an, kecuali di Jabung dan Kedungmonggo, kehidupan wayang topeng di daerah-daerah lain nampak telah sangat menurun karena beberapa sebab sehingga dewasa ini para pemain dari desa-desa yang lain banyak yang kemudian bergabung dengan rombongan wayang topeng dari dua desa yang disebutkan terakhir, yaitu Jabung, Kecamatan Jabung bekas Kawedanan Tumpang dan Dusun Kedungmonggo, Desa Karangpandan, Kecamatan Pakisaji, bekas Kawedanan Kepanjen ( Murgiyanto \& Munardi, 1978/79: 7-8)

Sepanjang tahun 1980-an hingga tahun 1990-an, partisipasi masyarakat dan juga sejumlah instansi swasta dan pemerintah sangat besar. Hal ini dibuktikan adanya usaha-usaha pemasyarakatan kembali pertunjukan wayang topeng yang ada di berbagai daerah. Kini perkumpulan yang masih dapat tampil yaitu perkumpulan Wayang Topeng Karya Bakti dari Desa Jabung yang diketuai oleh Pardjo; perkumpulan Wayang Topeng Sri Marga Utama dari Desa Glagahdowo yang dipimpin oleh Rasimoen; perkumpulan Wayang Topeng Asmarabangun dari 
Desa Kedungmonggo, dan perkumpulan Wayang Topeng Candrakirana dari Desa Jambuer pimpinan Barjo Jiono

Chattam AR seorang seniman wayang topeng, salah satu murid dari Karimoen menceritakan perihal salah seorang tokoh wayang topeng bernama Wij dari Dusun Kopral, Sukowilangun. Wiji merupakan salah satu tokoh yang sejajar dengan Reni dari Polowijen atau Yai Nata dari Slorok. Wiji baru diketahui ketokohannya oleh seniman-seniman tari di Malang sekitar tahun 1985. Waktu itu Wiji sudah berusia sekitar 110 tahun lebih (tahun 1985). Menurut catatan Chattam AR, ketika Wiji Masih muda seringkali pentas di pendapa Kabupaten Malang. Waktu itu yang menjadi Bupati di Malang adalah Raden japan, sekitar akhir abad XIX.

Wiji salah satu tokoh wayang topeng dari daerah Sumberpucung menceritakan pada Chattam AR tentang perkumpulan wayang topeng pimpinannya. Pementasan terakhir di pendapa Kabupaten Malang sekitar tahun 1960. Setelah itu banyak anggotanya yang memutuskan untuk mengikuti program transmigrasi ke Sumatera (Chattam A.R., wawancara 3 Maret 2010).

Pada akhir tahun 2000 perkumpulan wayang topeng yang masih aktif pentas berasal dari dua desa yaitu (1) Perkumpulan Wayang Topeng Asmarabangun dari Dusun Kedungmonggo, Kecamatan Pakisaji, (2) Perkumpulan Wayang Topeng Sri Marga Utama dari Dusun Geladahdowo, Kecamatan Tumpang, dan (3) Perkumpulan Wayang Topeng Karya Bakti dari Dusun Jabung. Bahkan di Dusun Gasek dua tahun berselang telah mendirikan perkumpulan Wayang Topeng yang dibina oleh Misdi (salah satu anggota dari perkumpulan Karya Bakti) dengan nama Dharmo Langgeng.

Selain keempat perkumpulan topeng yang disebutkan di atas, dua tahun terakhir ini di daerah Wijiombo, Gunungkawi mementaskan kembali repertoar tari topeng untuk upacara bersih desa. Tahun ini (2004) diselenggarakan pada tanggal 18 Januari 2004

Perkumpulan wayang topeng yang dikemukakan tersebut secara bervariasi memiliki repertoar konvensional, yaitu kisah romantik yang disebut Lakon Panji. Adapun lakon-lakon yang dianggap tradisional, terdiri atas (1) Rabine Panji, (2) Sayembara Sadalanang, (3) Walangwati - Walangsumirang, (4) Gunungsari Kembar, (5) Panji Laras, (6) Panji Kembar, (7) Kayu Apyun, (8) Wadhal Werdhi, (9) Lembu Gumarang, (10) Melatih Putih Edan, (11) Sekar Tenggek Lunge Jangge, (12) ader Bang Sisik Kencana, dan (13) Gajah Abuh atau Kudanarawangsa. Selain Lakon Panji, juga ada beberapa perkumpulan wayang topeng yang nyajikan lakon Mahabarata, masyarakat se tempat menyebut dengan lakon Purwa. Lakon Purwa ini sangat digemari masyarakat Malang sekitar tahun 1950-an. Bahkan masyarakat di lereng pegunungan Tengger sebelah barat seringkali mempertunjukan lakon Murwakala untuk ruwatan. Informasi tentang adanya Lakon Purwa pada wayang topeng dibenarkan oleh M. Soleh AP dan Chatam AR, dan diperkuat oleh tokoh-tokoh topeng di berbagai daerah sekitar Malang, seperti Madya Utama dari Desa Jatiguwi, Bardja Djiono dari Desa Jambuwer, Karimoen dari Dusun Kedungmonggo, Watiru dari Dusun Senggreng, dan Gimon dari Dusun Glagahdowo, Kusnan Ngaisah dari Dusun Slelir.

Di daerah Malang bagian selatan sekitar lembah sungai Metro dan waduk Karangkates pernah popular wayang topeng yang menampilkan Lakon Menak. Chattam AR menduga, bahwa perkumpulan wayang topeng yang pernah dipelopori oleh mbah Wiji banyak dipengaruhi oleh tradisi membaca Serat Menak. (ChattamAR, wawancara 14Agustus 2010).

\section{PERUBAHAN KEBUDAYAANDALAM ASPEK WAKTU}

Perubahan kebudayaan dalam aspek waktu adalah cara pandang secara diaktonis, yaitu melihat perubahan kebudayaan dari skwen waktu ke waktu, dalam mencermati Wayang Topeng Malang sebagai wujud kebudaayaan masyarakat Malang sudah barang tentu sangat terkait dengan aspek tersebut.

Jika menyimak pemahaman van Peursen, perubahan kebudayaan dibagi menjadi tiga tahap yaitu: tahap Mistis, Ontologis, dan Fungsional. (1) Tahap mistis adalah sikap manusia yang sangat tergantung pada kekuatan dan sugesti alam dan lingkungannya. Sehingga berbagai sikap dan tindakan selalu memperhitungkan kekuatan dan sugesti dari kekuatan roh-roh dan dewa-dewa penguasa alam raya, (2) Tahap Ontologis adalah tahap keingin tahunan manusia tentang segala sesuatu dengan kemampuannya berpikir, (3) Tahap Fungsional adalah tahap manusia mengambil jarak dengan berbagai objek yang ingin diketahui, hal tersebut yang menjadi ciri dri manusia modern (1976:18).

Jika menyimak pemikiran tersebut di atas, maka dapat diperhatikan perkembangan Wayang Topeng Malang sebagai berikut:

Topeng secara umum dipahami sebagai benda yang terkait dengan fungsi menutup wajah, atau disebut juga dengan wajah kedua dari manusia. Sehingga dapat ditemukan berbagai pengertian yang terkait dengan topeng, yaitu Kedok atau Tapel. Topeng dipahami sebagai tiruan wajah yang dibentuk atas bahan dasar yang tipis atau ditipiskan, dengan memperhitungkan kelaikan untuk dikenakan di muka wajah manusia, sehingga wajah yang mengenakannnya sebagai dan atau seluruhnya tertutup (Sedyawati, 1993:1). Topeng dalam budaya Jawa mempunyai perkembangan tersendiri, baik sebagai kegiatan ritual ataupun sebagai pertunjukan. Semula topeng adalah sebuah benda yang wujudnya sebagai peniruan wayah leluhur, seperti kepala keluarga, marga, atau suku (Kusmayati, 1990: 6, Hadi, 2006: 81). Topeng seringkali dikenali juga sebagai penggambaran tokoh tertentu yang berbgai sifatnya ditonjolkan dengan bantuan sistem simbolis yang canggih, yang menggabungkan warna wajah, bentuk hidung, bentuk mata, 
bentuk alis, dan bentuk mulut (Beuvier, 2002: 252).

Seperti yang telah dikemudkan, bahwa dinamika perkembangan Wayang Topeng Malang mengalami berbagai fase. Setidaknya para peneliti sebelumnya telah meyakini bahwa budaya topeng ditumbuhkan dari masa Jawa Timur, yaitu sebagai penutup wajah orang atau tokoh yang meninggal dunia.

Ketika di Jawa Timur pada masa itu digubah cerita-cerita baru, rupanya diikuti pula dengan diciptakannya bentuk dramatari yang baru yaitu Raket. Th. Pigeaud menduga bahwa dramatari tak bertopeng ini membawakan cerita Calonarang. Tetapi RM. Soedarsono menduga bahwa kemungkinan besar bukan cerita Calonarang yang ditampilkan, tetapi cerita Panji. Dugaan penulis in berdasrkan pada tiga karakter yang digambarkan dalam pertunjukan itu, yaitu Shori, Tekes, dan Citada. Shori adalah Sang Pahlawan (Panji), salah seorang Tekes adalah Sang Putri (Candrakirana), dan Gitada adalah Sang Penyanyi dan Pelawak (Punakawan; pada cerita Panji versi baru adalah Bancak). Kitab Negarakertagama memberitakan bahwa 'Nyanyian Sang Raja adalah sesuatu yang berbeda, yang menyebabkan para penonton terpesona..., Ia (Sang Raja) juga melawak, ... pendapat bahwa pendeta pertapa baradah dalam cerita Calonarang melawak seperti yang dikemukakan oleh pigeaud kurang bisa dibenarkan. Di samping itu Raket yang juga disebut Gambuh dalam cerita Wangbang Wedeya, dan Gambuh d bali adalah dramatari opera yang membawakan certia Panji (RM. Soedarsono, 1997: 90-91)

\section{PERUBAHAN KEBUDAYAAN DALAMASPEK LINGKUNGAN}

Malang menjadi daerah yang terbuka semenjak pemerintahan Kolonial Belanda, sudah dimulai adanya perencanaan pada sektor perekonomian sehingga ikut menjadi jalur internasional (melalui Surabaya) dan kemudian daerah sekitarnya ikut terakses. Malang resmi diduduki oleh pemerintah Kolonial Belanda sejak tahun 1767, yaitu setelah Belanda mematahkan perlawanan Pangeran Singosari, Malayakusuma, salah seorang keturunan Suropati. Pengambilalihan kekuasan atas Pangenan Malayakusuma tersebut dimasukkan dalam rechtstreeksbestuurd gebied (daerah yang langsung diperintah Belanda) Pada tahun 1771 secara resmi daerah tersebut menjadi salah satu kabupaten di wilayah karesidenan Pasuruan. (Tim Penyusun Sejarah Jawa Timur,1978:111-

112). Sejak saat itu tercatat nama Bupati Malang di antaranya Raden Tumenggung Kretanegara (....- 1822), Raden Bupati Panji Wilasmoro (1823-1839). Raden Tumenggung Noto Diningrat (1839-1884), Raden Tumenggung Ario Noto Diningrat (1884-1898), Suryo Adi Ningrat (1898-1934), dan Ario Adipati SA.M. (1934-1942)(Wojowasito, 1976:65:74).

Pada tahun 1767 penduduk Malang diperkirakan sekitar 1000 kepala keluarga. Untuk mencapai daerah Malang dari Pasuruan masih agak jauh yaitu berjarak $50 \mathrm{~km}$, yang ditempuh dengan menggunakan pedati kurang lebih selama dua hari. Sementara di daerah Malang selatan banyak ditumbuhi belukar dan didiami oleh perusuh. Ini berarti bahwa daerah Malang bagian selatan belum dibuka, baik untuk lahan pertanian maupun perkebunan. Daerah Lawang (utara kota Malang) dibuka pertama kali karena tanahnya subur dan udaranya sejuk. Hal ini memungkinkan untuk digunakan sebagai perkebunan kopi (cultures). Pada tahun 1800 di daerah Malang secara umum telah menjadi ladang pertanian dan juga perkebunan kopi ( Tim Penyusun Sejarah Jawa Timur, 1978:112-113).

Menyimak laporan Pigeaud (1938) bahwa pemukiman dan perekonomian di Malang sudah lama berkembang. Salah satu Bupati yang memimpin daerah Malang tercatat nama bupati Ario Adipati Sam, yang memerintah antara tahun 1934-1942. Priode tersebut merupakan pemerintahan Bupati Malang menjelang masa Kemerdekaan Republik Indonesia. Berdasarkan informasi Pigeaud (1938) yang diperoleh dari Bupati Malang Adipati Ario Surioadiningrat yaitu bahwa wayang topeng di kabupaten Malang tersebar di berbagai desa.

Pada tahun 1930-an tersebut para pembelajar Wayang Topeng yang menjadi tontonan utama di Kabupaten Malang. Bahkan, para pemilik perkebunan kopi seringkali mendatangkan perkumpulan Wayang Topeng untuk menghibur. Seperti pengalaman Kakek Karimoen yang menjadi penari di derah mbangeran Wijiombo Gunungkawi.

Menjelang masa kemerdekaan, Wayang Topeng di Malang mengalami masa vakum, hal ini dikerenakan oleh kondisi dan situasi lingkungan yang tidak memungkinkan. Karena masyarakat lebih mementingkan keselamatan jiwa.

Pada umumnya masyarakat diberbagai desa dalam wilayah pengungsian yang tempatnya berpindah-pindah, berbagai harta dan juga perlengkapan kesenian pada umumnya ditinggalkan.

Kondisi tersebut berlangsung hingga melampai zaman Jepang. Wayang Topeng tidak diberitakan. Beberapa narasumber tidak mengingat benar, karena masa itu merupakan masa yang sangat sulit. Perekonomian dan lapangan pekerjaan sangat sulit, bahkan bahan-bahan pakian tidak dapat diperoleh. Maka perlengkapan serta pengadaan perkumpulan Wayang Topeng di Malang memang benar-benar tidak mampu digerakan. Bahkan kondisi ini berlangsung hingga agresi Meliter hingga tahun 1949. Waktu itu Karimoen ketika masih remaja. Dia bersama orang tuanya, dan beberapa penduduk desa mengungsi ke daerah Gunungkawi. Ke arah barat-selatan Malang. Kurang lebih selama dua bulan dalam pengungsinan, pada suatu hari kembali kerumah untuk melihat kondisi rumah yang ditinggalkan. Ternyata berbagai perabot dan perlengkapan topeng semuanya hilang. Maka pada masa itu sudah tidal lagi dapat menyelenggarapan pementasan.

Memasuki era tahun 1950-an kondisi politik belum stabil, Wayang Topeng mulai mengalami pertumbuhan di berbagai desa. Termasuk pada 
perkumpulan yang dipimpinan ayah Karimoen. Untuk menumbuhkan kembal perkumpulan Wayang Topeng, ayah Karimoen menjual 2 ekor sapi.

Pertumbuhan Wayang Topeng dipicu oleh persebaran Wayang orang yang berasal dari Surakarta dan Semarang. Akan tetapi persebaran Wayang Orang tersebut hanya terbatas di tingkat kota (kotamadya). Sementara masyarakat di desa-desa tidak mampu menjangkau tontonan kelasik tersebut. Kondisis in memberikan suasana yang kondosof terhadap pertumbuhan Wayang Topeng di berbagai desa di Malang. Kepopuleran Wayang Topeng di berbagai dusun di wilayah Malang salah satunya adalah disebabkam oleh besarnya minat masyarakat yang ingin mendapatkan hiburan. Karena penyajian Wayang Topeng waktu itu sangat sederhana, yaitu digelar di halaman rumah, penerangan yang digunakan adalah lampu minyak atau petromax. Dalang yang membawakan narasi tidak menggunakan pengeras suara.

Pada tahun 50-an, merupakan masa keemasan seni pertunjukan Wayang Topeng Malang. Wayang Topeng yang dipimpin oleh ayah Karimoen pada waktu musim panen raya selalu berkeliling ke berbagai desa hingga satu bulan. Ketika mengakiri masa pementasan, setiap anggota dapat beli kaus dari bahan katun, dan membawa beras putih kurang lebih $15-20 \mathrm{~kg}$ setiap orang. Masa kejayaan tersebut ternyata tidak terlalu lama, akhir tahun 1950-an, kepopuleran Wayang Topeng Mulai terancam oleh perkembangan Ludruk yang berasal dari Surabaya. Maka berbagai perkumpulan Wayang Topeng hanya bertahan di desa masing-masing untuk memenuhi kebutuhan masyarakat setempat, seperti untuk memeriahkan hajatan pernikahan atau khitanan, sementara yang lain untuk memenuhi nadhar.

Beberapa perkumpulan yang kini masih mampu bertahan, sementara perkumpulan lain sudah lama tidak lagi dapat bangkit. Daerah Pucangsongo, hanya mampu bertahan hingga tahun 1980-an, yaitu setelah meinggalnya tokoh penari halus bernama Samut. Palawijen yang sangat populer sekitar awal abad XIX, hanaya bertahan sekitar tahun 70-an, yaitu sepeninggalnya tokoh bernama Patawi. Kusnan Ngaisan adalah orang terahir yang menjadi saksi perkumpulan wayang topeng di desa Slilir, bahwa perkumpulan wayang topeng didesanya sudah berakhir sekitar tahun 1960-an. Kasus punahnya perkumpulan di berbagai desa di Malang pada umumnya disebabkan oleh perubahan kondisi lingkungan, yaitu berubahnya kondisi desa yang terisolir menjadi desa yang mampu diakses progam pembangunan. Selain dari pada itu disebabkan oleh menyempitnya halamanhalaman rumah yang pada waktu dahulu memang menjadi ruang sosial masyarakat. Mengingat pada masa populernya Wayang Topeng memang menggunakan halaman sebagai ruang pentas.

Perkumpulan topeng di berbagai desa tidak lagi mampu berkembang di mungkinkan karena oleh perubahan lingkungan sosial, salah satunya adalah orentasi kepercayaan masyarakatnya. Mengingat hingga penyajian Wayang
Topeng masih mengikuti tata cara tradisi, yaitu menyajikan sesaji dan juga membakar hio (kemenyan lidi), dan menggunakan doa-doa tradisional.

Menguatnya emosi religius masyarakat sangat terasa benar sekitar akhir tahun 1960-an, hal tersebut diikuti dengan tumbuhnya tempat-tempat ibadah dihampir setiap kampung, atau dusun, Maka para tokoh Wayang Topeng mulai merasa kesulitan untuk melakukan regenerasi, terutama para remaja. Hal tersebut dikarenakan banyak orang tua yang tidak merelakan anaknya terlibat sebagai penari topeng. Kondisi ini yang menunjukan perubahan orentasi cara berpikir masyarakat yang sudah memasuki tarap ontologis. Dasara utamanya adalah pemahaman religi yang menabukan sikap dan prilaku meyakini adanya roh-roh yang dianggap menjadi pelindung masyarakat.

\section{PERUBAHAN KEBUDAYAAN DALAM ASPEK MEDIA}

Pada tahun 1980-an, pemerintah mulai meluncurkan program-program penggalian dan menguatkan sentra-sentra seni pertunjukan yang hampir semuanya musnah di pertengahan tahun 1960-an. Taslah Harsono, putra Karimoen dari Kedungmonggo dan Pardjo kepenakan Kangsen dari Jatiguwi dibawa ke Bali, Keduanya dibelajarkan mengukir topeng selama kurang lebih 1 bulan. Harapannya, kedua pengukir topeng dari Malang tersebut dapat memperbaiki teknik pengukir yang umumnya dikerjakan dengan sebuah pisau pangot.

Di samping itu, sekitar tahun 1970-an. Tim obsertasi dari Surabaya yang dipimpin oleh AM Munardi seorang guru Tari dari Konservatori Tari (Konri) Surabaya menuju salah satu perkumpulan yang dipimpin oleh Kangsen, seorang luarah di dusun Jabung, Setelah itu, wayang Topeng Malang yang membawakan lakon Panji mulai dikenal, bahkan ketika pada tahun 1972 diselengarakan festival Panji Nusantara di Pandaan-Pasuruan, dan festival topeng di Yogyakarta pada tahun 1976. Wayang Topeng Malang seperti mutiara yang ditemukan kembali. Terlebih pada tahun 1980-an Karimoen, Kasdu (pengendang) dan Chattam AR (muridnya) dipercaya sebagai dosen luar biasa di Sekolah Tinggi Kesenian Wilwatikta (STKW) Surabaya. Demikian juga ketika IKIP Surabaya membuka program studi Pendidikan seni Tari, Karimoen juga dipercaya untuk mengajarkan tari topeng,

Masuknya seni tari sebagai media penndidikan, ternyata mendorong pengemasan penyajian Wayang Topeng menjadi tari lepas yang iringannya dikemas berupa rekaman kasset, pertama kali iringan tari Topeng dikassetkan pada tahun 1979. Sentra Wayang Topeng yang dijadikan objek adalah perkumpulan Asmarabangun dari Dusun Kedungmonggo.

Memasuki melenium ke 2. M. Soleh Adipramono mengembangkan penyajian Wayang Topeng dengan format penyajian seperti Wayang Orang, menggunakan kelir (layar bergambar), koreografinya dikembangkan sesuai 
tuntuan cerita. Bahkan dikemas dalam bentuk tayangan VCD. Adapun lakon yang digarap diangkat dari sastra panji, yaitu lakon Panji Reni.

Sementara Wayang Topeng di berbagai daerah yang masih menggunakan lakon-lakon yang lasim dipentaskan, khususnya yang menjadi paporit masyaraka adalah lakon Rabine Panji (Panji Menikah), bahkan lakon ini telah dimodivikasi menjadi lakon Rabine Gunungsari (Gunungsari Menikah). Bahkan seniman yang tergabung di Dewan Kesenian Malang pernah mencoba mengkreasikan lakon Rabine Bapang.

Pengaruh adanya perkembangan teknologi, khususnya teknologi multimedia yang mendesak pola pikir masyarakat lebih bersifat fungsional. Maka hal tersebut yang menjadikan para pendukung wayang topeng selalu berorentasi pada aspek komersial. Ketrampilan yang telah mereka miliki menjadi bernilai vinensial.

\section{DAFTAR PUSTAKA}

Amir, Hazim.1997. Nilai-Nilai Etis dalam Wayang. Jakarta: Pustaka Sinar Harapan

Anderson, Benedict. 2002. (cetakan2). Imagined Comunities. Terj. Omi Intan Naomi. INSIST \& Pustaka Pelajar, Yogyakarta.

Bouvier, Helene. 2002. Lebur!; Seni Musik dan Pertunjukan dalam Masyarakat Madura. Yayasan Obor Indonsia: Jakarta.

Eriksen, Thomas Hylland. 2009. Antropologi Sosial dan Budaya. Terj. Yosef Maria Florisan. Ledalero. Maumere.

Dana, I Wayan. 2011. "Menjelajah Jejak Topeng dalam Budaya Indonesia dari Masa ke Masa. Pidato Pengukuhan Jabatan Guru Besar Pada Fakultas Seni Pertunjukan Institut Seni Indonesia Yogyakarta. Dissjikan di depan Rapat Senat Terbuka Institut Seni Indonesia Yogyakarta Pada Tanggal 16 Oktober 2010. ISI, Yogyakartas

Hadi, Y Sumandyo. 2006. "Wayang Topeng dan Cerita Roman Panji dalam Perjalanan Budaya" dalam buku Jaringan Makna Tradisi hingga Kontemporer: Kenangan Purna Bakti untuk Prof. Soedarso, Sp. M.A. BP ISI Yogyakarta: Yogyakarta.

Hidajat, Robby. 2008. Wayang Topeng Malang. Gantar Gumelar \& Jurusan Seni \& Desain Fak. Sastra UM: Malang.

Kusmayati, A.M. Hermien. (1990). "Makna tari Dalam Upacara Di Indonesia”. Artikel pada : Pidato Ilomiah pada Dies Natalis Keenam ISI Yogyakarta,21 juli 1990. Institut Seni Indonesia: Yogyakarta.

McCracken, Grant. 2008. Trasformations: Indentity Construction in Contemporary Culture. Indiana university Press.Bloomington.
Pegeaud, Th. 1991. Javaanse Volksvertoningen: Bijdrage tot de bescrijsing van lond en volk. Terj. Muhammad Husopdo Pringgokusumo. (tidak diterbitkan). Milik Perpustakaan Rekso Pustoko Istana Mangkunegaran Surakarta.

Peursen, van C.A. 1976. Strategi Kebudayaan. Kanisius. Yogyakarta.

Ras, J.J. 1985. Bunga Rampai Sastra Jawa Mutahir, Terj. Hersri, Jakarta: Grafitiperss.

Sachari, Agus \& Sunarya, Yan Yan. 2001. Wacana Trasformasi Budaya, ITB, Bandung.

Samuel, Hanneman. 2010. Geneologi Kekuasaan Ilmu Sosial Indonesia; dari Kolonial Belanda hingga Modernisme Amerika. Kepik Ungu. Depok.

Sedyawati, Edi.1993. "Topeng dalam Budaya". Jurnal Seni Pertunjukan Indonesia. Masyarakat Seni Pertunjukan Indonesia: Bandung.

Soedarsono, R.M. 1997. Wayang Wong: Drama Tari Ritual Kenegaraan di Keraton Yogyakarta: Gadjah Mada University Press: Yogyakarta.

Timoer, Soenarto. 1989. "Mengungkap Asal Usul dan Identitas Pertunjukan Topeng Jawa Timur" Makalah disajikan dalam forum seminar temu budaya daerah Jawa Timur . Surabaya: Kantor wilayah Dep. P dan K propensi Jawa Timur. 